педагогічну етику / В. О. Сухомлинський // Вибр. тв.: у 5 т. - К. : Рад.шк., 1977. - Т. 5. - С. 591-600. 12. Управлінські аспекти соціальної роботи: [курс лекцій] / за заг. ред. М. Ф. Головатого. - К. : МАУП, 2004. - 260 с. 13. Черевко В. П. Формування комунікативної компетентності майбутнього менеджера у процесі професійної підготовки: дис. ... канд. психол. наук : 19.00.07 / В. П. Черевко. - К., 2001. 247 с. 14. Шпак О. Економіка освіти - складова професіоналізму вчителя / О. Т. Шпак // Молодь і ринок. - 2010. - №1-2. - С.13-18.

УДК 371.132:372

B. В. Садова,

кандидат пед. наук, доиент,

Криворізький педагогічний інститут

ДВНЗ «Криворізький національний університет»

\title{
ПРОЦЕСУАЛЬНІ АСПЕКТИ ФОРМУВАННЯ ІСТОРИКО-ПЕДАГОГІЧНОЇ КУЛЬТУРИ СТУДЕНТІВ
}

Садова В. В. Процесуальні аспекти формування історико-педагогічної культури студентів.

Стаття містить теоретичне обгрунтування історико-педагогічної культури студентів як навчально-особистісного феномену; на грунті аналізу наукової літератури подається експлікація терміна «історико-педагогічна культура»; уточнюються процесуальні аспекти формування історико-педагогічної культури студентів у навчально-виховному середовищі філологічних факультетів.

Ключові слова: студенти педагогічного інституту, історико-педагогічна культура, майбутній учитель.

Садовая В. В. Процессуальные аспекты формирования историко-педагогической культуры студентов.

Статья содержит теоретическое обоснование историко-педагогической культуры студентов как учебно-личностного феномена; на основе анализа научной литературы подается экспликация термина «историко-педагогическая культура», уточняются процессуальные аспекты формирования историкопедагогической культуры студентов в учебной среде филологических факультетов.

Ключевые слова: студенты педагогического института, историко-педагогическая культура, будущий учитель.

Sadova V. V. Process aspects concerning formation of students' history-and- pedagogy culture.

The article deals with some theoretical foundations of students' history-and-pedagogy culture as an education-and-personality phenomenon; on the basis of science literature analysis the explication of the «history-and-pedagogy culture» term is presented; the process aspects concerning the formation of students' history-and-pedagogy culture in the educational field of philology faculties are detailed.

Key words: students of a pedagogical institute, history-and-pedagogy culture, future teacher.

«Однобічний спеціаліст є або брутальним емпіриком, або вуличним шарлатаном» [7, c. 156], - це зауваження видатного лікаря, педагога, суспільного діяча М. Пирогова, висловлене ним у середині XIX ст. на сторінках статті «Питання життя» (1856 р.) набуває неабиякої актуальності в перші десятиліття XXI століття. Наша доба є добою «вузької спеціалізації»: дуже часто спеціалісти, які здійснюють наукові розвідки, не обізнані 3 напрямами наукової роботи колег у межах одного навчального чи наукового закладу. Видатні науковці С. Капіца, С. Курдюмов, Г. Малинецький на прикладі природничих наук констатують: «... «фізик» на фізичних факультетах стає так багато (фізика напівпровідників, моря, землі, плазми, Сонця, елементарних часток тощо), що колеги зараз дуже приблизно уявляють і математичний апарат, і експериментальні методики, що використовуються на сусідній кафедрі» [4, с. 8]. I резюмують: не даремно Д. Менделєєв пропонував готувати спеціалістів 3 математики, хімії, фізики й біології на одному факультеті як засіб запобігання однобічної професійної чи наукової спрямованості. Історія наукових відкриттів XX ст. підтверджує справедливість цього твердження, адже сьогодні 
нове знання народжується на перетині декількох дисциплін. Цей факт повною мірою стосується педагогічної освіти: педагогічний інститут за своїм призначенням повинен здійснювати підготовку людини-фахівця 3 широким спектром професійних властивостей та якостей, інтеграцією різноманітних компетентностей у структурі особистостіпрофесіонала, адже робота педагога зберігає універсальний характер поза часом чи місцем здійснення педагогічної діяльності. Сучасний учитель, викладач високого фахового рівня повинен бути втіленням енциклопедичної освіти, широкої ерудованості. Вважаємо, що одним із шляхів формування такої «професійної універсальності» може стати історикопедагогічна культура студента, майбутнього вчителя.

У добу, коли спільнота прагне активно пізнавати свою історію, невідкладною є потреба осмислення і творчого використання традицій європейської (сформованої в докорінним чином відмінних, позатоталітарних, історичних та соціокультурних умовах) та вітчизняної освіти. Важливо об'єктивно оцінювати інтелектуальний та духовний спадок світової педагогіки, розуміти його цінність, здійснювати «сучасне прочитання» цього досвіду як «іншого знання», звільненого від ідеологічних викривлень XX ст., властивих вітчизняній суспільній ментальності. Таке «прочитання» історико-педагогічного досвіду поволі перетворюється в науковий імператив реформування вищої педагогічної сфери, спрямований на підготовку фахівців нового рівня.

Генеза феномену історико-педагогічної культури особистості відбувається на тлі наукових досліджень, присвячених аналізу педагогічної (В. Грехньова, Н. Ничкало, Г. Соколова), професійно-педагогічної (І. Бердніков, І. Пальшкова) культури студентів, висвітлення особливостей формування професійної культури вчителя (Т. Бутенко, І. Ісаєв, А. Мудрик, Г. Нагорна, I. Прокопенко, В. Сластьонін). Беремо до уваги напрацювання науковців у галузі дослідження особливостей фахової підготовки спеціаліста в умовах вищого навчального закладу (С. Архангельський, С. Вітвіцька, О. Дубасенюк, І. Зязюн, I. Кобиляцький, О. Малихін). Експлікацію поняття «історико-педагогічна культура» знаходимо в працях Б. Бім-Бада, С. Сгорова, Г. Коджаспірової, Г. Корнєтова, Д. Латишіної, О. Любара, А. Рацула. Науковці аналізують цей термін з різних методологічних засад, та попри наявні розбіжності в тлумаченнях, погляди російських, українських науковців збігаються в одному: історико-педагогічна культура визначається ними як вислід історикопедагогічних знань, передбачених планами та програмами вищих навчальних закладів, результат традиційного викладання історико-педагогічних дисциплін у вищій школі в поєднанні з комплексом особистих якостей студента, досвідом здійснення рефлексивнопедагогічних дій.

На нашу думку, в дослідженні феномену історико-педагогічної культури варто зважати на загальну соціокультурну детермінацію наукового пізнання в західній гуманітаристиці (Дж. Агассі, Т. Кун, І. Лакатос, П. Фейерабенд), де нині чітко зартикульована необхідність «подолання кумулятивізму в експлікації моделей росту наукового знання» (В. Яковлєв [12]), здійснюється дослідження основ науки в широкому соціальному контексті.

Ураховуючи сказане вище, метою статті визнаємо розкриття сутності феномену історико-педагогічної культури на тлі досягнень світової та вітчизняної гуманітаристики, визначення та характеристику процесуальних аспектів іiі формування у студентів вищих педагогічних навчальних закладів.

Класичні (Фома Аквінський, І. Кант, Е. Б. Тайлор, К. Шмідт та ін.) та сучасні інтерпретації культури (І. Зязюн, О. Закович, Е. Оніщенко та ін.) як поліфункціонального феномену дозволяють розглядати iї з еволюційної позиції, відповідно до якої науковий спадок і досягнення минулого є невід'ємною частиною загальносвітових та національних надбань. Серед розмаїття класифікацій культур увагу педагогів привертає оригінальна класифікація американського етнографа М. Мід [6], яка запропонувала здійснювати розмежування на основі здатності людини вчитися, пізнавати навколишній світ, - вчитися або в попередників, або в наступників. Здатність людини вчитися у своїх попередників продукує постфігуративну культуру (діти вчаться на прикладах батьків і в такий спосіб 
пізнають світ), суб'єкти культурної діяльності (і діти, і дорослі) вчаться у своїх ровесників (кофігуративна культура); суб'єкти культурної діяльності (дорослі) розвивають здатність вчитися у своїх наступників (дітей), - ознака культури префігуративної. Спробуємо узагальнити висхідні підстави розуміння культури як педагогічного феномену.

Суттєвий вплив на актуалізацію проблем розуміння культури спричинили феноменологія, герменевтика, структуралізм та постструктуралізм, постмодернізм, які актуалізували поняття «сенс», «цінність», «розуміння», «комунікації», «дискурсивна практика». Педагогіка дозволяє перевести загальнофілософські здобутки в практичну площину, адже, за оцінкою філософів, ці стрижневі поняття не $є$ повною мірою «вбудованими в систему категорій і принципів епістемологічного аналізу» [12], значною мірою залишаючись на периферії філософських досліджень культури й науки як частини культури.

Науковцями визнано, що сьогодні базисним принципом сучасної епістемології $€$ необхідність «повернути» людину в структури виробництва наукового знання, себто сформулювати концептуальну схему пізнавальної діяльності, у якій визначені контури осмислення знань у контексті культури, що перетворюють логіку формальних понять науки в характеристику соціального буття людини [12]. Фактично, сучасна філософія, яка надає загальний методологічний інструментарій педагогіці, пропонує науковцямпедагогам здійснити той шлях, який свого часу пройшов видатний німецький філософ і педагог Й.Ф.Гербарт (до речі, очоливши кафедру філософії й педагогіки в Кенігзьберзькому університеті після смерті I. Канта): проблеми цілепокладання в педагогіці він радить розв'язувати в ареалі філософії, а сама педагогіка, за його висловом, повинна стати «практичною філософією» [3, с. 294]. Отже, феномен історико-педагогічної культури студента не варто тлумачити винятково з позицій утилітаризму (вислідом якого $\epsilon$ поширені в сучасному науково-освітянському просторі компетентнісний, діяльнісним, ресурсний підходи), необхідно «повернути» суб'єкт навчального процесу (студента) в структури продукування наукового знання і на грунті пізнання осмислити історикопедагогічну навчальну інформацію в контексті культури, перетворивши логіку формальних понять педагогічної науки в характеристики буття, характеристики існування педагогічних знань у соціально-педагогічному середовищі, осмислити в такий спосіб шляхи й умови формування студента як конкурентоздатного професіонала.

Як основні передумови тлумачення сутності історико-педагогічної культури, змістового наповнення цього поняття можемо виокремити:

а) культурно-історичну зумовленість розуміння будь-якого педагогічного поняття, явища чи процесу;

б) взаємозв'язок пізнання та самопізнання суб'єкта педагогічного процесу;

в) залежність від наявних комунікативних засобів (мова й мовлення як «обрій» розуміння: за визначенням творців «лінгвістичного перевороту» воно (розуміння) реалізується в процедурах інтерпретацій, неминучий конфлікт яких і є об'єктивною умовою розуміння).

Під час визначення сутності історико-педагогічної культури студента зважаємо на міждисциплінарний характер історико-педагогічного знання, необхідність здійснення його цілісної сучасної інтерпретації (один із шляхів такої інтерпретації - подолання наявної й донині роздільної лакуни між вітчизняною та зарубіжною історією педагогіки), осмислення загального досвіду людства в галузі виховання й освіти.

Історико-педагогічна культура студента видається нам інтегральним, до певної міри дискреційним (таким, що дозволяє суб'єкту навчальної діяльності діяти на власний розсуд) феноменом, що грунтується на засвоєнні світових та вітчизняних культурно-історичних надбань в освітній галузі та відіграє спонукальну роль в особистісному й майбутньому професійному зростанні студента.

Висвітленню процесуальних аспектів формування історико-педагогічної культури студентів передує аналіз їі структури. Для розроблення структури історико-педагогічної 
культури студента як інструментарію використовуємо термін «концепт» (лат. conceptus поняття, думка, уявлення). Цим терміном послуговуються логіка, культурологія, лінгвокраїнознавство (для двох останніх синонімічними, рівнозначними $є$ поняття логоепістеми, лінгвокультуреми, морфологеми), $\epsilon$ задіяним він і в педагогічних дослідженнях. У широкий культурологічний вжиток термін увів Ю. Степанов (1997р.), конкретизувавши його змістовий план «як своєрідний згусток культури в свідомості людини. I, з іншого боку, концепт - це те, засобом чого людина ... сама входить в культуру, а в деяких випадках і впливає на неї» [9, с. 125]. У структурі історикопедагогічної культури студента концепт відіграє роль мікромоделі (знання, ціннісні орієнтації, досвід використання студентом набутих знань в навчальній та позанавчальній діяльності), і сама історико-педагогічна культура $\epsilon$ органічним синтезом дотичних концептів. Виокремлення концептів здійснюється залежно від того, які іiі складники набувають актуалізації. Коротко схарактеризуємо кожен концепт структури історикопедагогічної культури студента та процесуальні аспекти іï формування.

Когнітивно-гносеологічний кониепт. Засвоєння студентами історико-педагогічного матеріалу здійснюється в логіці історичного пізнання. Студенти, вивчаючи цикл педагогічних дисциплін, опановують навчальну інформацію про історичні умови виникнення виховання, педагогічної теорії, про основні етапи розвитку освіти й педагогіки, про погляди найбільш видатних іiі представників. Грунтовне ознайомлення майбутніх бакалаврів, спеціалістів і магістрів 3 педагогічною спадщиною найвидатніших зарубіжних та вітчизняних педагогів дозволяе зануритись в історико-педагогічний контекст, а розуміння ролі й значення освіти та шкільної справи активізує пізнавальномотиваційні механізми діяльності особистості.

Пізнання минулого $€$ запорукою адекватного розуміння сучасності: осмислення студентами історико-педагогічної інформації, роздумів видатних педагогів і діячів освіти минулих часів про чинники соціалізації особистості, дослідження факторів, що впливають на її формування, висвітлення сутності авторських виховних та дидактичних концепцій допомагає розумно підходити до оцінки сучасних педагогічних феноменів, адже ретельний аналіз численних «педагогічних новацій», здійснений на грунті історикопедагогічної обізнаності, дозволяє зрозуміти, що здебільшого вони, за своєю сутністю, $є$ «переспівом» добре знаних педагогічних думок чи рекомендацій, більшою чи меншою мірою врахованих сучасних (надзвичайно мінливих) соціально-політичних реалій. I хоч у цьому «немає нічого, що було б варте осуду» (А. Піскунов [3, с. 7]), однак автори цих «новітніх концепцій» повинні, як мінімум, посилатися на попередників, тим більше, що сучасний соціокультурний контекст модернізації вітчизняної освіти формує оцінні судження суспільства про певні зрушення у вітчизняній освітній галузі в основному завдяки висловлюванням, які не підтверджуються серйозними статистичними даними. Тож історико-педагогічна культура є запобіжником від некоректності й некомпетентності, студенти привчаються оцінювати досвід минулого, виокремлюючи в ньому ті ідеї, які сприяють прогресу педагогічної теорії в різні історичні епохи, усвідомлюють взаємозв'язок демократизації виховання і суспільного прогресу. Історико-педагогічні знання допомагають і майбутньому вчителю-практику, і майбутньому науковцю розумно діяти в сучасних умовах, осмислювати професійно-педагогічну діяльність та свої погляди на неї.

Праксеологічний конщелт історико-педагогічної культури студента складається 3 практичних умінь, навичок, наявного пізнавального досвіду: студенти повинні розуміти й пояснювати історичні зв'язки сучасної педагогіки з передовими педагогічними системами минулого, дотримуватись принципів наступності; призвичаїтись за період навчання у вищій школі творчо використовувати досвід минулих поколінь у розв'язанні проблем, які стоять сьогодні перед педагогічною наукою й практикою. У науковій педагогічній царині (i не лише педагогічній), на жаль, не поодинокими є випадки заміни логічної наукової аргументації посиланнями на «авторитети». Призвичаїти студента до самостійної розумової роботи, 
розвинути уміння формулювати обгрунтовані критичні судження, обирати аргументи на користь своєї точки зору - важливе завдання професійної підготовки. До того ж опановані методи конкретно-історичного аналізу студенти використовують не лише щодо педагогічних явищ і процесів, а й до широкого кола суспільно-гуманітарних проблем, тож самі ці методи набувають поліфункціонального значення. Уміння аналізувати й виявляти раціональні й гуманістично орієнтовані педагогічні засоби $\epsilon$ основою потенційної методичної компетентності майбутнього випускника вищого навчального закладу, основою для формування й розвитку його педагогічних прогностичних здібностей. Себто складники праксеологічного концепту історико-педагогічної культури повинні забезпечити наступність професійного формування педагога.

Адаптуючи рекомендації Дж. Рубіна та I. Томпсона (1982, [11]), можемо стверджувати, що складники праксеологічного концепту історико-педагогічної культури студента формуються на основі:

- виявів індивідуальності на грунті опанування історико-педагогічної інформації;

- «зовнішньої» організації процесу навчання (наприклад, залучення можливостей компаративного аналізу у процесі компонування та інтерпретації історико-педагогічної інформації, адже порівняльний аналіз є невід'ємним елементом будь-якої творчої діяльності, повноцінного використання контексту тощо);

- «внутрішньої» організації процесу навчання (подолання невпевненості, стимулювання виявів творчих здібностей тощо).

Уміння, навички й досвід пізнавальної діяльності як складники гносеологічного концепту історико-педагогічної культури створюють підстави для самореалізації, особистісного самовдосконалення. Тому цілком логічним $є$ виокремлення в структурі історико-педагогічної культури студента ціннісно-особистісного концепту.

Ціннісно-особистісний кониепт. Розуміння історико-педагогічної культури як особистісної цінності повинно сформуватися внаслідок вивчення циклу педагогічних дисциплін. В. Сластьонін, I. Ісаєв та Є. Шиянов визначають, що педагогічні цінності розрізняються за рівнем свого існування: аксіологічне «Я» як система ціннісних орієнтацій містить не тільки когнітивні, а й емоційно-вольові компоненти, що відіграють роль внутрішнього орієнтиру індивіда. Ціннісне «Я» студента синтезує як соціально-педагогічні, так і професійно-групові цінності. Науковці виокремлюють цінності, пов'язані 3 затвердженням особистістю своєї ролі в соціальному та професійному середовищі, цінності спілкування й саморозвитку творчої індивідуальності, цінності самореалізації (творчий, варіативний характер педагогічної праці) й цінності, що надають можливість задовольняти прагматичні потреби [8, с. 74]. На наш погляд, цінністю педагогічної освіти, майже втраченою в наш час, $є$ інтелігентність.

Загальновизнаною $є$ думка про те, що проблема інтелігентності як властивості особистості була визнана в першій половині XIX ст., в Російській імперії, де й виникає термін «інтелігенція» як калькована форма 3 латини (intelligentsia). У німецькій мові також використовується цей термін як синонім позначення групи освічених людей, а сучасна Британська енциклопедія посилається на російські джерела. Вважається, що на східнослов'янському просторі початок дискусії про інтелігентність виходить 3 листів О. Герцена, адресованих I. Тургенєву. Ідея О. Герцена про те, що бездуховна порожнеча нівелює творчі поривання, була сприйнята сучасним для нього суспільством у якості висхідного орієнтиру переосмислення світоглядних установок, що сприяють розвитку соціуму. Оскільки розвиток вимагає безперервної інтелектуальної творчості, що втілюється в критичне осмислення наявних суспільних форм «задля привнесення в них істини й справедливості» (П. Ткачов [10]), то й вимагається певний тип особистості, який би зосереджував у собі раціонально-наукову та духовну сутність. Наш співвітчизник i сучасник, доктор технічних наук Ю. Зіньковський в останніх публікаціях взагалі висловлюється доволі категорично з цього питання: на його думку, доодержання вищої освіти бажано допускати людей зі сформованими якостями духовності, моралі та 
загальної культури, «виховання духовного початку у вищій школі є тим більш значущим, чим менше уваги йому приділяється в загальній школі» [2, с. 22]. У XIX ст. П. Лавров назвав такий тип людини, яка поєднує в собі наукове знання з високою моральністю, критично мислячою особистістю. Сенс явища, втіленого в цьому визначенні, полягає в тім, що особистість, яка досягла високої щаблини свого розвитку, виробила в собі ідеал людської гідності. Втілення цього ідеалу в дійсність перетворилося на її життєвий сенс. Тому така особистість за рівнем самосвідомості й за критичним ставленням до навколишньої дійсності представляє собою досконалу людську індивідуальність.

Цікаве тлумачення розмежувань інтелігенції знаходимо в працях М. Бердяєва: для нього «інтелігентщина» - це та частина інтелігенції, яка керується гуртковими інтересами (й нині словосполучення «наукова школа» використовується не лише як наслідок визнання наукових досягнень, а й як спроба позначити сфери наукового впливу, коло вузькокелейних, інколи й просто меркантильних інтересів, далеких від справжньої науки), прагненням до утилітарної оцінки світу, іiі «інтерес... до філософії вичерпується потребою в філософській санкції ऑiі суспільних настроїв та прагнень» [1, с. 28]. Місію ж інтелігентності М. Бердяєв вбачає у прагненні до об'єктивних цілей і універсальних принципів. Тому ціннісно-особистісний концепт історико-педагогічної культури студента «несе відповідальність» як за загальну гуманітарну обізнаність, так і за прагнення (вислід потреб, мотивів та ціннісного ставлення) особистості займатися наукою, мистецтвом, публіцистикою, в решті решт, просто бути інтелігентною людиною.

У XX столітті конформізм практично всіх людей, які вважали себе інтелігентами, або яких кваліфікували як інтелігенцію, відіграв свою роль у формуванні негативного ставлення до неї. На часі - повернення ціннісних основ інтелігентності, оскільки саме інтелігенція повинна створювати ідеологію суспільства («ідеологія» - без політичного забарвлення, у значенні продукування ідей, а саме на брак ідеології в українському суспільстві нині нарікають найчастіше і в наукових колах, і в засобах масової інформації).

Отже, здійснений аналіз структури та процесуальних аспектів формування історикопедагогічної культури студентів підтверджує своєчасність і важливість теоретичного обміркування проблем, пов'язаних 3 формуванням цього професійно-особистісного феномену. Фасилітаторами формування історико-педагогічної культури студента об'єктивно визначено євроінтеграційні процеси, соціально значущі стандарти сучасної української вищої освіти, суспільна потреба в енциклопедично обізнаних педагогахфахівцях. Особистість майбутнього вчителя повинна органічно поєднувати педагогічний професіоналізм, власне предметні знання, духовно-моральні основи. Як інтегральне явище, історико-педагогічна культура дозволяє долати інерційність педагогічних систем та технологій, відкриває нові обрії пізнання педагогічної дійсності.

\section{Література}

1. Бердяев Н. А. Философская истина и интеллигентская правда. Вехи / Н. А. Бердяев // Вехи. Из глубины. - М. : Молодая гвардия, 1991. - С.24-43. 2. Зіньковський Ю. Виховання і навчання. Протиріччя в єдності / Ю. Зіньковський // Вища школа. - 2012. - С. 20-29. 3. История педагогики и образования. От зарождения воспитания в первобытном обществе до конца XX в. / под ред. А. И. Пискунова. - М. : ТЦ Сфера, 2001. - 512 с. 4. Капица С. Синергетика и прогнозы будущего / С. П. Капица, С. П. Курдюмов, Г. Г. Малинецкий. - [Электронный ресурс]. - Режим доступа: sergey.@kapitza.ras.ru. 5. Лавров П. Л. Исторические письма / Петр Лаврович Лавров. - СПб., 1905. - 28 с. 6. Мид М. Культура и преемственность. Исследование конфликта между поколениями / М. Мид // Культура и мир детства. - [Электронный ресурс]. - Режим доступа: www.countries.ru/library/texts/mid.htm 7. Пирогов Н. И. Вопросы жизни / Н. И. Пирогов // Хрестоматия по истории школы и педагогики в России / сост. С. Ф. Егоров. - М. : Просвещение, 1971. - С.155-172. 7. Сластенин В.А. Общая педагогика / Сластенин В. А., Исаев И. Ф., Шиянов Е. Н. - М. : Гуманит. центр ВЛАДОС, 2003. - Ч.1. - 288 с. 8. Степанов Ю. Константы. Словарь русской культуры. Опыт исследования / Ю. Степанов. - М. : Наука, 1997. - 67 с. 9. Ткачев П. Н. Сочинения в двух томах / Петр Никитич Ткачев. - М. : Мысль, 1975-1976. - Т.1. С.14-43. 10. Щукин А. Н. Лингводидактический энциклопедический словарь: более 2000 единиц / 
Анатолий Николаевич Щукин. - М. : Астрель АСТ: Хранитель, 2007. - 746 с. 11. Яковлев В. Ю. Ценностно-смысловые основания научного познания : автореф. дис. на соискание уч. степени док. филос. наук : 09.00.01 / В. Ю. Яковлев. - Киров, 2009. - 47 с.

\section{ЗМІСТ ПСИХОЛОГО-ПЕДАГОГІЧНОЇ ПІДГОТОВКИ МАЙБУТНЬОГО ВИКЛАДАЧА ДО ПРОФЕСІЙНОЇ ТВОРЧОЇ ДІЯЛЬНОСТІ}

Сгадова В. В. Зміст психолого-педагогічної підготовки майбутнього викладача до професійної творчої діяльності.

У статті розглянуто зміст психолого-педагогічної підготовки майбутнього викладача до професійної творчої діяльності, висвітлено різні види навчальної діяльності студентів, які забезпечують формування в них творчих умінь.

Ключові слова: методологічні, теоретичні, методичні й технологічні знання, творчі вміння, умови здійснення психолого-педагогічної підготовки студентів до творчої діяльності.

Сгадова В. В. Содержание психолого-педагогической подготовки будущего преподавателя к профессиональной творческой деятельности.

В статье рассмотрено содержание психолого-педагогической подготовки будущего преподавателя к профессиональной творческой деятельности, освещены различные виды учебной деятельности студентов, которые обеспечивают формирование у них творческих умений.

Ключевые слова: методологические, теоретические, методические и технологические знания, творческие умения, условия осуществления психолого-педагогической подготовки студентов к творческой деятельности.

Sgadova V. V. The content of future lecturer psychology-pedagogical preparation to professional creative activity.

The content of psychology-pedagogical preparation of future lecturers to professional creative activity is analyzed. Different forms of students' educational activity which develop their creative skills are highlighted.

Key words: methodological, theoretical, methodical and technological knowledge, creative skills, conditions providing psychology-pedagogical preparation of students to professional creative activity.

Зміни, що відбуваються в сучасному суспільстві, потребують переорієнтації освіти як на творчий розвиток особистості, так і на підготовку майбутніх викладачів до його здійснення. Ось чому в умовах розбудови національної системи освіти актуальною є проблема підготовки викладача як особистості, що характеризується широкою ерудицією, високою професійною майстерністю, творчим підходом до організації навчально-виховного процесу. У методичному аспекті підготовка майбутніх викладачів охоплює формування емоційноціннісного ставлення до творчого процесу, опанування студентами знань і вмінь, пов'язаних 3 організацією творчого пошуку, педагогічного експерименту, запровадження інновацій у практику вищої школи.

Питання педагогічної творчості та творчого потенціалу досліджується у працях А. Алексюка, В. Бондаря, В. Буряка, Є. Бондаревської, В. Кан-Калика, А. Капської, Н. Кичук, М. Нікандрова, Я. Пономарьова, Н. Тализіної, О. Хижної.

Психолого-педагогічні аспекти проблеми, що розглядаються, знайшли відображення в публікаціях К. Гуревича, В. Зінченка, Л. Кондрашової, В. Мадзігона, Ю. Мальованого, С. Максименка, П. М'ясоїда, О. Павлютенкова, О. Савченко, Н. Токара, Р. Хмелюк, Б. Федоришина, М. Янцура. Методології педагогічних досліджень присвячено роботи 